\title{
CD 57 EXPRESSION ON LYMPHOCYTES PRESENT IN THE CAECUM AND CAECAL TONSILS IN BROILERS INFECTED WITH EIMERIA TENELLA
}

ILIĆ TAMARA, ALEKSIĆ-KOVAČEVIĆ SANJA, KNEŽEVIĆ MILIJANA and DIMITRIJEVIĆ SANDA

Faculty of Veterinary medicine, University of Belgrade, Serbia

(Received 12 $2^{\text {th }}$ December 2008)

In order to detect and establish the expression of the CD57 lymphocyte population in the caecum and caecal tonsils in broilers, immunohistochemical studies of tissue samples of broilers experimentally infected with E. tenella at 21 days of age were carried out. Immunohistochemical investigations were performed with the aid of the avidin-biotin technique (LSAB), by using mouse monoclonal antiCD57 antibodies. Increased immunoreactivity of the lamina epithelialis, mucosal lamina propria and caecal submucosa was detected as early as two days after infection, increasing at its highest at the end of the fourth day after infection. On the fifth, sixth and seventh day after infection the degree of expression of CD57 lymphocytes in the caecal mucosa of experimental birds decreases. The immunoreactivity of the tissue of the stroma of the mucosal and submucosal lamina propria of the caecal tonsils was most intensive the fourth, sixth and seventh day after infection. A discrete immunoreactivity decrease was present during the fifth day after infection. The so established CD57 lymphocyte population activity in the caecum and caecal tonsils substantiates the existence of NK cytotoxic activity of intraepithelial lymphocytes, as well as the role of these cells in the intestinal mucosa defense mechanisms against intracellular microorganisms.

Key words: caecal coccidiosis, caecal tonsils, chick, immunohistochemistry

\section{INTRODUCTION}

The diffuse mucosal lymphocyte population in the chick's intestine consists of intraepithelial lymphocytes (IEL) and lamina propria lymphocytes (LLP). IEL in birds are a heterogeneous population which consists of $\mathrm{T}$ lymphocytes, $\mathrm{B}$ lymphocytes and NK cells. IEL display a higher NK cytotoxic activity when compared to LLP, and represent the first line of defense of the intestinal mucosa against infection with coccidiae and other intracellular microorganisms (Lillehoj, 1989; Barcinski and Costa-Moreira, 1994; Lillehoj and Trout, 1996; Lillehoj, 1998; Lillehoj and Lillehoj, 2000; Sharma et al., 2000; Myamoto et al., 2002; Sklan, 2005). The caecal tonsils, bursa of Fabricius, the diffuse mucosal lymphocytic 
population, the diverticulum of Mekel and Payer's plates make up the intestinal lymphatic tissue in birds (Sharma, 1997; Jeurissen et al., 1999; llic et al., 2004).

The activity of NK cells in the IEL intestinal population has been established in a number of species: mice (Dillon and Mcdonald, 1984), rats (Flexman et al., 1983), piglets (Wilson et al., 1986), guinea pigs (Arnaud-Battandier et al., 1979) and humans (Hogan et al., 1985). NK cell activity in broilers has been described in the spleen (Lillehoj and Ruff, 1987), peripheral circulation (Lillehoj, 1989; Breed et al., 1996) and intestines (Chai and Lillenhoj, 1988).

NK cells play a major role in the primary defense of the organism against tumors, bacteria, viruses and parasites (Barcinski and Costa-Moreira, 1994; Korbel et al., 2004). Increased NK cellular activity is present during infections with a number of intracellular parasites, such as Leishmania, Trypanosoma, Toxoplasma and Neospora (Flyn and Sileghem, 1994; Mertens et al., 1999; Lillehoj et al., 2000; Nakano et al., 2002; Schmieg et al., 2003; Antunez and Cardoni, 2004; Korbel et al., 2004; Maley et al., 2006).

Intraepithelial lymphocytes morphologically are described as large granular lymphocytes (LGL). They are the major NK activity effectors in the intestinal tissue of birds and mammals. LGL are involved in the development of host resistance against intestinal infections (Flexman et al., 1983; Hogan et al., 1985; Lillehoj and Ruff, 1987; Lillehoj, 1989; Breed et al., 1996; Miyamoto et al., 2002). Lymphocytes with large cytoplasmatic granules can be found in the peripheral blood, spleen, lungs and lymph modes in mice; fimbriae in the oviduct and endocervix in rabbits; oviduct in birds; thymus, kidney and liver in rats and the reproductive tract of male rats and monkeys (Luini et al., 1981; Rolstad et al., 1986; Khan and Hashimoto, 2001).

The aim of this study was to detect the subpopulation of NK cells in broilers and to prove their importance in the defense of the submucosa against Eimeria tenella.

\section{MATERIAL AND METHODS}

1. Experimental animals. This study involved a total of 100 one day old broilers, type "Hybro". The broilers were divided into two groups (control group 20 birds and experimental group - 80 birds). The experimental birds were infected per os at 21 days of age with $5 \times 10^{5}$ infective E. tenella oocysts. The subsequent seven days after infection, chicken health was monitored, as well as the clinical state, mortality rate and pathoanatomical and pathohistological changes of the organs.

2. Specimen preparation. Tissue samples of the caecum and caecal tonsils were taken for pathohystological studies and fixed in $10 \%$ buffered formalin. After processing the samples, paraffin $5-8 \mu \mathrm{m}$ slices were dyed by the HematoxillinEosin (HE) and Periodic Acid Shiff (PAS) methods. For immunohistochemical studies tissue samples were fixed in B-5 mercury fixative (Buffered Formaldehyde Sublimate), $\mathrm{pH} 7$.

3. Immunohistochemistry. CD57 lymphocytes in the caeca and caecal tonsils of infected and control broilers were labelled by immunohistochemical 
method with avidin-biotin, using monoclone antibodies against human CD57 lymphocytes (HNK1 cells). The required material consisted of: primary monoclonal antibodies (DAKO-NK1, CD57 diluted in TBS (1:50), Dako No. M1014); 2) secondary antibody (Biotinlyated Link, Dako No. K0675); 3) tertiary antibody (Streptavidin - HRP, Dako No. K0675); 4) solutions for diluting, rinsing and blocking of endogenous peroxidase; 5) agent for visualization of the reaction (Amino Ethyl Carbazole - AEC, Dako No. K0672); 6) standard controls.

During the LSAB laboratory procedure (Labelled Streptavidin Biotin), all dilutions and rinsing procedures were carried out with TBS (Tris Buffered Saline, $\mathrm{pH}$ 7.5). Endogenous peroxidase was blocked with $3 \% \mathrm{H}_{2} \mathrm{O}_{2}$. After visualization with chromogen (AEC), samples were contrasted with haematoxillin (Meyer).

4. Cell count. CD57 lymphocytes were counted on a JENAMED 2 (ZEISS) microscope at a magnification of 1:400 (the overall area of the field of vision at this magnification was $0.25 \mathrm{~mm}^{2}$ ). Detailed comparison of the obtained cell counts was carried out by counting the cells per $\mathrm{mm}^{2}$ in a virtual mesh obtained from the software packet AxioVision 3.1. (MEASURE PLUGIN, 2002) on a microscope AXIOSKOP 2 (ZEISS).

5. Statistical analysis. The significance of differences between groups was calculated using Student's t-test with a probability level of $95 \%$ and $99 \%$.

\section{RESULTS}

In the caecum and caecal tonsils of infected broilers differences in distribution and frequency of the studied CD57 population were established. Lymphocytes were labelled with monoclonal mouse antibodies against human NK cells. The applied DAKO - NK1 binds to intraepithelial lymphocytes, which results in an accumulation of a visible, finely granulated red precipitate in the cytoplasm and membranes of the cells.

The second day after infection a low reactivity degree manifested as few, singular CD57 positive cells in the caecal superficial epithelium and epithelium of the crypts of Lieberkuhn $\left(179 / \mathrm{mm}^{2}\right)$ and caecal tonsils $\left(211 / \mathrm{mm}^{2}\right)$, as well as in the stroma of the caecal lamina propria mucosae was described. In the epithelial cells trophozoites were detected. At the same time the corium was infiltrated with lymphocytes and heterophilic granulocytes. In the caecal tonsils singular immunoreactive diffuse cells in the interfollicular areas of the corium and tunica submucosa were described.

On the third day after infection an increased number of immunoreactive cells was present in the lamina epithelialis, in the epithel of the Crypts of Lieberkuhn and in the stroma of the lamina propria mucosae of the caecum $\left(226 / \mathrm{mm}^{2}\right)$ and caecal tonsils $\left(278 / \mathrm{mm}^{2}\right)$. An increased degree of immunoreactivity was recorded in the germinative centers of the caecal tonsils, with dominant positive cells in the interfollicular zones and in the epithelium of the crypts of Lieberkuhn, whose mitotic index was increased (Fig. 5 and Fig. 6). The epithelial cells in the crypts of Lieberkuhn were hypertrophic, hyperplastic and vacuolized, with the first schizont generation present. Between the glandular cells within the corium, an abundant infiltrate consisting of lymphocytes and heterophilic granulocytes was detected. 


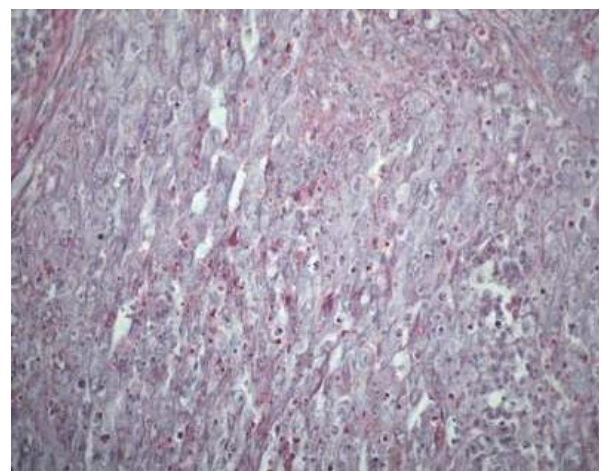

Figure 1. Chicken caecum, $4^{\text {th }}$ day after infection, PAS, 40X

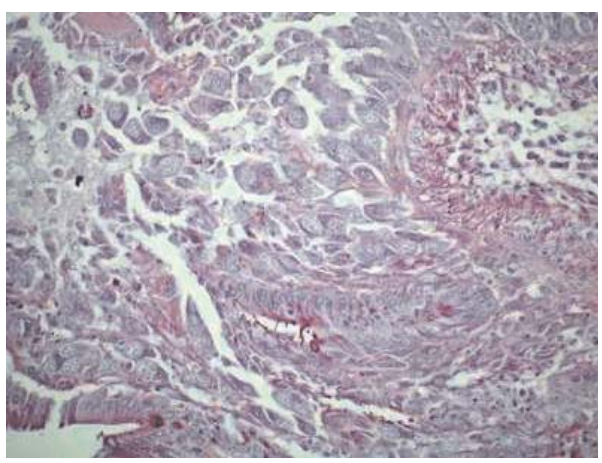

Figure 3. Chicken caecum, $5^{\text {th }}$ day after infection, PAS, $40 \mathrm{X}$

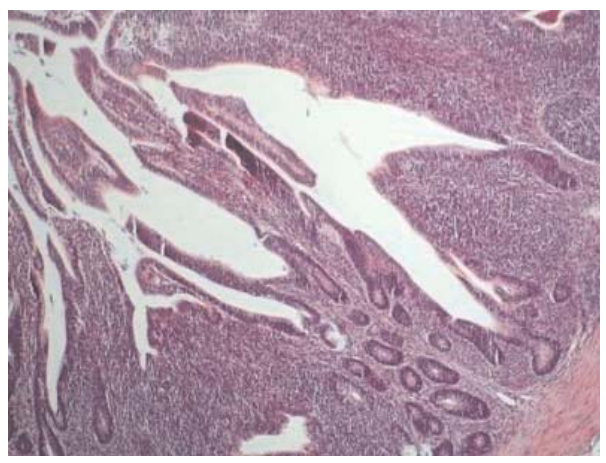

Figure 5. Caecal tonsile, $3^{\text {rd }}$ day after infection, PAS, $20 \mathrm{X}$

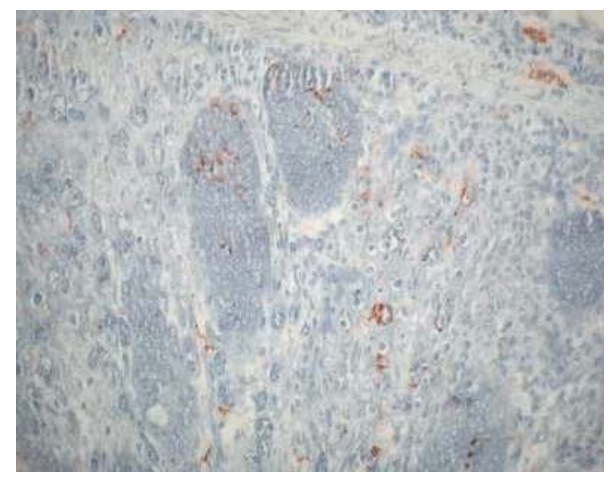

Figure 2. Chicken caecum, $4^{\text {th }}$ day after infection, expression $\mathrm{CD}_{57}, \mathrm{IHC}, 40 \mathrm{X}$

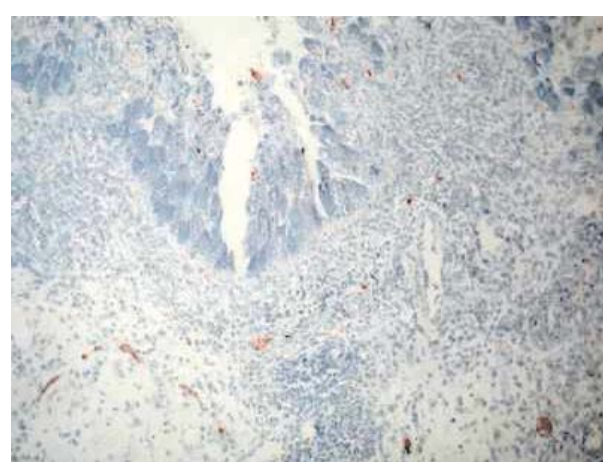

Figure 4. Chicken caecum, $5^{\text {th }}$ day after infection., expression $\mathrm{CD}_{57}$, IHC, $20 \mathrm{X}$

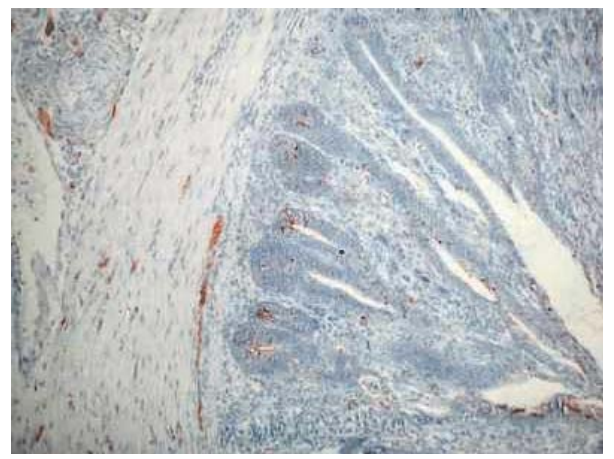

Figure 6. Caecal tonsile, $3^{\text {rd }}$ day after infection, expression $\mathrm{CD}_{57}, \mathrm{IHC}, 20 \mathrm{X}$ 


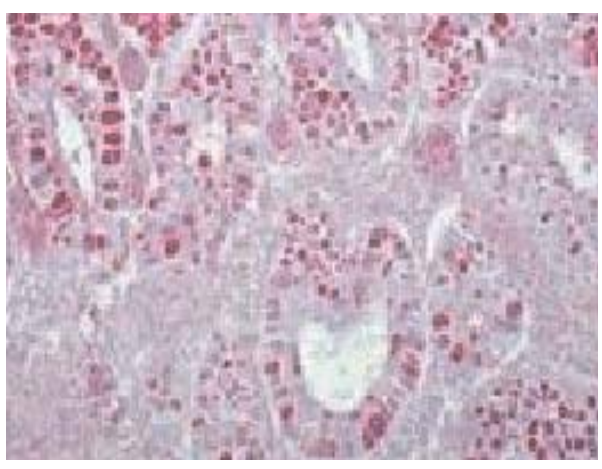

Figure 7. Caecal tonsile, $7^{\text {th }}$ day after infection, PAS, 40X

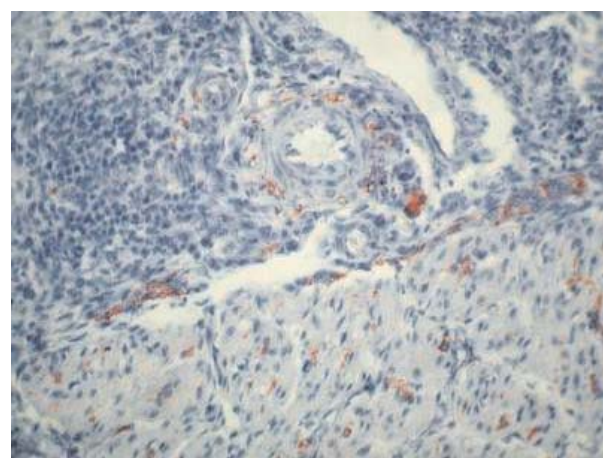

Figure 8. Caecal tonsile, $7^{\text {th }}$ day after infection, expression $\mathrm{CD}_{57}$, IHC, $40 \mathrm{X}$

The fourth day after infection the lamina propria of the caecum was necrotized, and the largest portion of the lamina propria presented a necrotic detritus with schizonts and merozoites of the first generation, lymphocytes, erythrocytes and heterophilic granulocytes. The CD57 cells were found diffusely distributed in the epithelium of the Lieberkuhn crypts and in some areas of the stroma. In these areas the number of CD57 cells was significantly increased $\left(308 / \mathrm{mm}^{2}\right)$ (Fig. 1 and Fig. 2). The marked increase in the number of immunoreactive cells in all layers of the caecal tonsils was most severe in the corium and submucosa $\left(343 / \mathrm{mm}^{2}\right)$.

The fifth day after infection the mucosal lamina propria was necrotized. In the epithelium of the Lieberkuhn crypts and in the stroma of the caecum and caecal tonsils schizonts and merozoites of the second generation, erythrocytes and heterophilic granulocytes, as well as singular immunoreactive cells were a common finding (Fig. 3 and Fig. 4). In these layers the overall number of CD57 positive cells was decreased, and its counting was impaired due to the arising hemorrhagic-necrotic enteritis. The tunica submucosa and the tunica muscularis of the caecal tonsils were edematous, hyperemic and densely infiltrated with lymphocytes, heterophilic and eosinophilic granulocytes. Diffusely spread in the submucosa were clusters of positive cells $\left(276 / \mathrm{mm}^{2}\right)$, however a high degree of immunoreactivity was still present.

The sixth and seventh day after infection large portions of the mucosa of the caecum and caecal tonsils were filled with the necrotic detritus containing schizonts and merozoites of the second generation, micro and macrogamets, zygotes and oocists (Fig 7). The number of immunoreactive cells was decreased and they were individually localized in the proliferated epithelium of the remaining Lieberkuhn crypts and stroma of the lamina propria mucosae. In the caecal tonsils even more intense immunoreactivity was detected $\left(367 / \mathrm{mm}^{2}\right.$ the sixth day and $425 / \mathrm{mm}^{2}$ the seventh day). This was highest in the lamina propria of the mucosa and submucosa with a dominant lymphocytic reaction in the interfollicular areas. 
Reactivity, displayed as diffusely disseminated cells, was present in the epithelium of the necrotized Lieberkuhn crypts (Fig 8).

\section{DISCUSSION}

The lymphocytic CD57 population detected by humane CD57 antibodies was localized in the superficial epithelium, epithelium of the Lieberkuhn crypts, stroma of the caecal lamina propria mucosae and the submucosa of the caecum and caecal tonsils of non-infected broilers.

Increased immunoreactivity of the lamina epithelialis, lamina propria mucosae and caecal submucosa was recorded on the second day, being at its highest on the fourth day after infection. In the first three days after infection, immunoreactivity was high within the epithelium when compared to the stroma of the lamina propria. Intraepithelial lymphocytes showed morphological characteristics of large granulated lymphocytes (LGL) which specifically react with monoclonal CD57 antibodies. These lymphocytes are the major effectors of NK activity in the intestines of mammals and birds (Dillon and Mac Donald, 1984; Wilson et al., 1986; Chai and Lillehoj, 1988; Breed et al., 1996; Lillehoj et al, 2004; Sklan, 2005). Authors have described the presence of NK activity in the intestines of chicks infected with E. acervulina (Swinkles et al., 2007), as well as a gradual NK activity increase of IEL starting from the second day after infection (Lillehoj, 1989; Miyamoto et al., 2002).

Being localized in the most prominent histological structure of the intestine, i.e. in the area where the majority of ingested antigens comes into close contact with the host, IEL and LLP represent the first line of defense and play a major role in the local cellular immunological response (Mertens et al., 1999; llić et al., 2003).

On the fifth and sixth day after infection the degree of CD57 lymphocyte expression in the caecal mucosa decreases. This finding can be explained by the development of hemorrhagic and necrotic enteritis and the fact that in the preserved segments of the caecum different developing stages of the parasite are common, thus making difficult the identification of the expected cell population. The immunoreactivity of the submucosa is increased, and due to the antigenic stimulus of the second generation of coccidial schizonts the accumulation of lymphatic tissue in this histological layer of the caecum is evident.

In the stroma of the lamina propria within the caecal tonsils the expression of CD57 positive lymphocytes is directly related to the stage of $E$. tenella development, being most intensive the fourth, sixth and seventh day after infection. This finding is in agreement with previously published papers which explain the mechanisms responsible for the decrease in NK cell activity described to occur some time after infection (Lillehoj and Trout, 1996; Lillehoj and Lillehoj, 2000; Lillehoj et al., 2004). This was explained by the fact that Eimeria during acute infections may either directly or indirectly induce the suppression of the NK cell population. The direct decrease of NK cell activity is the result of intensive reproduction of the parasite. The indirect decrease in NK cell activity during the early stages of infection is the result of immunoregulative intraepithelial lymphocytes and macrophages within the broilers' gut (Chai and Lillehoj, 1988; 
Sharma, 1997; Raulet et al., 2001; Dalloul and Lillehoj, 2006; Dalloul et al., 2007; Miska et al., 2007).

The observed increase in the number of immunoreactive cells on the fourth, sixth and seventh day after infection is in agreement with previously published papers which confirm the increase in two phases of IEL NK activity during infections with $E$. maxima and $E$. tenella (Hong et al., 2006).

In the results obtained in our study the observed number of immunoreactive cells (in the caecum the 2, 3 and 4 day after infection, and in the caecal tonsils throughout the duration of the experiment) significantly differed $(P<0.01)$. Due to necrosis, profuse cell infiltration and detritus counting of cells was difficult on days 5,6 and 7 after infection. Hence, at this time the quantitative assessment of immunoreactivity was impaired.

The confirmed degree of expression of CD57 lymphocytes in the caecal tonsils proves the significant role of this secondary lymphatic organ in the development of the immune response to coccidial infection. This statement is highlighted by the fact that chicks at the age of 2 weeks have developed germinative centers in the lymphatic tissue of the caecal tonsils, these being the areas in which a high degree of antigen stimulation is achieved. The age of the chicken does not affect the formation of the germinative centers, as this depends mainly on the degree and duration of the antigen stimulus in the gut (Jeurissen et al., 1999). The named structures consist of nodular units which contain inside the follicles a number of M cells (Kitagwa et al., 2003). They are the most effective cells regard to antigen transport, and by pinocytosis and phagocytosis take up the antigens from the intestinal lumen and transfer them inside the follicles. There is a marked cooperation between the nodular units of the caecal tonsils (Pohlmeyer et al., 2005). In broilers the number of intraepithelial lymphocytes within the gut reaches its highest value at 6 weeks of age. The number of $M$ cells is significantly lower compared to IEL, but their role in the processing of antigens is very important as they are in direct relation to the epithelium, thus enabling the immune response to depend directly from the content of the gut's lumen (Sklan, 2005).

The obtained results show the importance of the increasing NK activity of IEL in the organization of the protection of the intestinal mucosa against intracellular organisms.

\section{CONCLUSION}

As the intestinal epithelium is in close contact to a large number of antigen stimuli, it is of no surprise the existence of a number of different lymphocyte effectors. The observed immunoreactivity of the CD57 lymphocyte population in the caecum and caecal tonsils, confirms the existence of NK cytotoxic activity of intraepithelial lymphocytes. They do not only self-limit the infection, but have an important role in the organization of the defense of the gut against infection with intracellular organisms. 


\section{ACKNOWLEDGMENT:}

This work was supported by a grant from the Ministry of Science, Technology and Development of the Republic of Serbia, IO 156010 and IO 143001.

Address for correspondence:

Dr Tamara llić

Faculty of Veterinary Medicine

11000 Belgrade, Serbia

Bul. oslobođenja 18

E-mail: damjanilic@yahoo.com

\section{REFERENCES}

1. Antunez MI, Cardoni RL, 2004, Trypanosoma cruzi: the expansion of NK, T and NKT cells in the experimental infection, Exp Parasitol, 106, 3-4, 85-94.

2. Arnaud-Battandier F, Bundy BM, O'Neill M, Beinenstock J, Nelson DL, 1979, Cytotoxic activities of GLUT mucosal lymphoid cells in guinea pigs, J Immunol, 121, 1059.

3. Barcinski MA, Costa-Moreira ME, 1994, Cellular response of protozoan parasites to host derived cytokines, Parasitol Today, 10, 352-5.

4. Breed DG, Dorrestein J, Vermeulen AN, 1996, Immunity to Eimeria tenella in chickens: phenotypical and functional changes in peripheral blood T-cell subsets, Avian Dis, 40, 1, 37-48.

5. Chai JY, Lillehoj HS, 1998, Isolation and functional characterization of chicken intestinal intraepithelial lymphocytes showing natural killer cell activity against tumour target cells, Immunol, 63, 111-7.

6. Dalloul RA, Lillehoj HS, 2006, Poultry coccidiosis: recent advancementsin control measures and vaccine development, Expert Rev Vaccines, 5, 143-63.

7. Dalloul RA, Bliss TW, Hong YH, Chouikha IB, Park DW, Keeler CL et al, 2007, Unique responses of the avian macrophage to different species of Eimeria, Molec Immunol, 44, 4, 558-66.

8. Dillon SB, MacDonald TT, 1984, Functional properties of lymphocytes isolated from murine small intestinal epithelium, Immunology, 52, 501.

9. Flexman JP, Shellam GR, Mayrhofer G, 1983, Natural cytotoxicity, responsiveness to interferon and morphology of intra-epithelial lymphocytes from the small intestine of the rat, Immunology, 48, 733.

10. Flynn JN, Sileghem M, 1994, Involvement of $\gamma \delta$ T cells in immunity to trypanosomiasis, Immunology, 83, 86-92.

11. Hogan PG, Hapel AJ, Doe WF, 1985, Lymphokine-activated and natural killer cell activity in human intestinal mucosa, J Immunol, 135, 1731-8.

12. Hong YH, Lillehoj HS, Dalloul, RA, Min W, Miska KB, Tuo W et al, 2006, Molecular cloning and characterization of chicken NK-lysin, Vet Immunol Immunopathol, 110, 3-4, 339-47.

13. Jeurissen SH, Wagenaar F, Janse EM, 1999, Further characterization of M cells in gut-associated lymphoid tissues of the chicken, Poult Sci, 78, 7, 965-72.

14. Khan MZI, Hashimoto $Y, 2001$, Large granular lymphocytes in the oviduct of developing and hormone treated chickens, Brit Poult Sci, 42, 2, 180-3.

15. Kitagawa $H$, Hosokawa M, Takeuchi T, Yokoyama T, Imagawa $T$, Uehara M, 2003, The cellular differentiation of $\mathrm{M}$ cells from crypt undifferentiated epithelial cells into microvillous epithelial cells in follicle-associated epithelia of chicken cecal tonsils, J Vet Med Sci, 65, 2, 171-8.

16. Korbel DS, Finney OC, Riley EM, 2004, Natural killer cells and innate immunity to protozoan pathogens, Int J Parasitol, 34, 13-14, 1517-28.

17. Lillehoj HS, Ruff M, 1987, Comparison of disease susceptibility and subclass-specific antibody response in SC and FP chickens experimentally inoculated with Eimeria tenella, E.acervulina or E.maxima, Avian Dis, 31, 112-9.

18. Lillehoj HS, 1989, Intestinal intraepithelial and splenic natural killer cell responses to Eimerian infections in inbred chickens, Amer Soc Microbiol, 57, 1879-84. 
19. Lillehoj HS, Trout JM, 1996, Avian gut-associated lymphoid tissues and intestinal immune responses to Eimeria parasites, Clin Microbiol Rev, 9, 3, 349-60.

20. Lillehoj HS, 1998, Role of T lymphocytes and cytokines in coccidiosis, Int J Parasitol, 28, 7, 107181.

21. Lillehoj HS, Lillehoj EP, 2000, Avian coccidiosis. A review of acquired intestinal immunity and vaccination strategies, Avian Dis, 44, 2, 408-25.

22. Lillehoj HS, Min W, Dalloul RA, 2004, Recent progress on the cytokine regulation of intestinal immune responses to Eimeria, Poult Sci, 83, 4, 611-23.

23. Luini W, Boraschi D, Alberti S, Aleotti A, Taglibue A, 1981, Morphological characterization of a cell population responsible for natural killer activity, Immunol, 43, 4, 663-8.

24. Maley SW, Buxton D, Macaldowie CN, Anderson CN, Anderson LE, Wright SE et al, 2006, Characterization of the immune response in the placenta of the cattle experimentally infected with Neospora caninum in early gestation, J Comp Pathol, 135, 2-3, 130-41.

25. Mertens B, Taylor K, Muriuki C, Rocchi M, 1999, Cytokine mRNA profiles in trypanotolerant and trypanosusceptible cattle infected with the protozoan parasite Trypanosoma congolense: protective role for interleukin 4, J Interferon Cytokine Res, 19, 59-65.

26. Miska KB, Fetterer RH, Lillehoj HS, Jenkins MC, Allen PC, Harper SB, 2007, Characterisation of makrophage migration inhibitory factor from Eimeria species infectious to chickens, Molec Bioch Parasitol, 151, 2, 173-83.

27. Miyamoto T, Min W, Lillehoj HS, 2002, Kinetics of interleukin - 2 production in chickens in fected with Eimeria tenella, Comp Immunol Microbiol Infect Dis, 25, 3, 149-58.

28. Nakano Y, Hisaeda H, Sakai T, Ishikawa H, Zhang M, Maekawa Y et al, 2002, Roles of NKT cells in resistance against infection with Toxoplasma gondii and in expression of heat shock protein 65 in the host macrophages, Microb Infect, 4, 1, 1-11.

29. Pohlmeyer I, Jörns J, Schumacher U, Van Damme EJM, Peumans WJ, Pfüller U et al, 2005, Lectin Histochemical Investigations of the Distal Gut of Chicks with Special Emphasis on the Follicleassociated Epithelium, $J$ Vet Med Series A, 52, 3, 138-46.

30. Raulet $D H$, Vance RE, McMahon CW, 2001, Regulation of the natural killer cell receptor repertoire, Annu Rev Immunol, 19, 291-330.

31. Rolstad B, Herberman RB, Reynolds CW, 1986, Natural killer cell activity in the rat. The circulation patterns and tissue localization of peripheral blood large granular lymphocytes (LGL), $J$ Immunol, 136, 8, 2800-8.

32. Schmieg J, Gonzales-Aseguinolaza G, Tsuj M, 2003, The role of natural killer T cell subsets against infection by the pre-erythrocytic stages of malaria parasites, Microbes Infect, 5, 6, 499-506.

33. Sharma JM, 1997, The structure and function of the avian immune system, Acta Vet Hung, 45, 3 , 229-38

34. Sharma MJ, Kim IJ, Rautenschlein S, Yeh HY, 2000, Infectious bursal disease virus of chickens: pathogenesis and immunosupression, Devel Comp Immunol, 24, 223-35.

35. Sklan D, 2005, Development of defense mechanisms in the digestive tract of the chick, J Appl Poult Res, 14, 437-43.

36. Swinkels WYC, Post J, Cornelissen JB, Engel B, Boersma WJA, Rebel JMJ, 2007, Immune responses to an Eimeria acervulina infection in different broilers lines, Vet Immunol Immunopathol, 117, 1-2, 26-34.

37. Wilson AD, Stokes CR, Bourne FJ, 1986, Morphology and functional characteristics of isolated porcine intraepithelial lymphocytes, Immunology, 59, 109. 


\title{
EKSPRESIJA CD $_{57}$ NA LIMFOCITIMA CEKUMA I CEKALNIH TONZILA BROJLERA INFICIRANIH SA EIMERIA TENELLA
}

\author{
ILIĆ TAMARA, ALEKSIĆ-KOVAČEVIĆ SANJA, KNEŽEVIĆ MILIJANA \\ i DIMITRIJEVIĆ SANDA
}

\begin{abstract}
SADRŽAJ
$\mathrm{U}$ cilju detekcije i utvrđivanja ekspresije $\mathrm{CD}_{57}$ populacije limfocita u cekumu i cekalnim tonzilama pilića, izvedeno je imunohistohemijsko ispitivanje tkivnih isečaka kod jedinki koje su 21. dana starosti eksperimentalno inficirane protozoom E. tenella. Ova ispitivanja su izvedena avidin-biotin tehnikom (LSAB), korišćenjem monoklonskih mišijih anti- $\mathrm{CD}_{57}$ antitela. Pojačana imunoreaktivnost laminae epithelialis, laminae propriae mukoze i submukoze cekuma zapažena je već drugog dana posle infekcije, sa najvećim intenzitetom krajem četvrtog dana. Petog, šestog i sedmog dana posle infekcije, stepen ekspresije $C_{57}$ limfocita u mukozi cekuma eksperimentalnih životinja se smanjivao. Imunoreaktivnost tkiva cekalnih tonzila najintenzivnija je četvrtog, šestog i sedmog dana posle infekcije, u stromi laminae propriae mukoze i submukozi, uz postojanje blagog pada u petom danu posle infekcije. Dokazana imunoreaktivnost $\mathrm{CD}_{57}$ populacije limfocita $u$ cekumima i cekalnim tonzilama, potvrđuje NK ćelijsku citotoksičnu aktivnost populacije intraepitelnih limfocita i ukazuje na važnu ulogu ovih ćelija u organizaciji odbrane crevne mukoze protiv intracelularnih mikroorganizama.
\end{abstract}

